
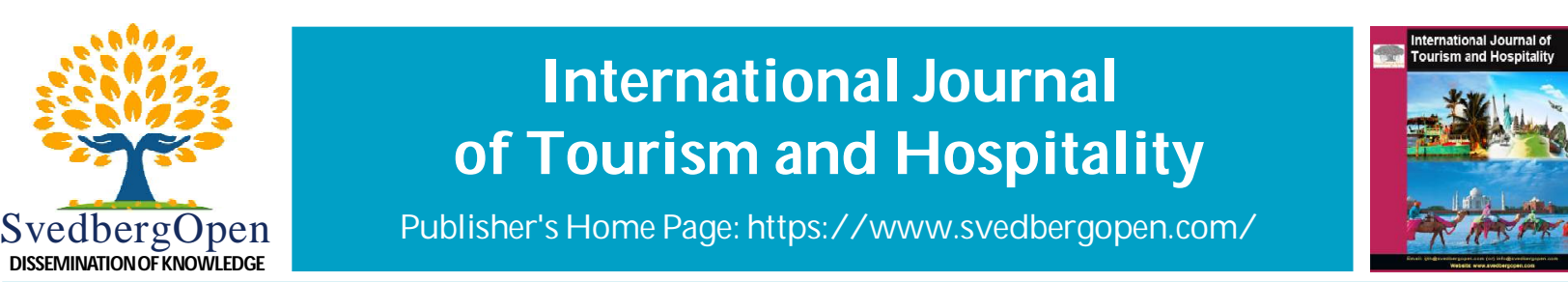

Research Paper

O pen A ccess

\title{
Sectoral Development of Cultural Tourism Centers in Kerala - A Study Based on the Specialities of Cultural Tourism Products in God's Own Country
}

Jaseela Thanikkad $^{1 *}$ and Shanimon, S. ${ }^{2}$

1'Assistant Professor NMSM Government College, University of Kannur, Kalpetta, Kerala 673122, India. E-mail: jaazthanikkad@gmail.com ${ }^{2}$ Assistant Professor, Government College Attingal, Thiruvananthapuram, University of Kerala, Government College Attingal. E-mail: shanimonimon@gmail.com

Article Info

Volume 1, Issue 4, October 2021

Received : 09 May 2021

Accepted : 18 September 2021

Published : 05 October 2021

doi: 10.51483/IJTH.1.4.2021.1-10

\begin{abstract}
Tourism is becoming a vibrant and significant contributor to the sustainable development of Kerala. The state offers a world-class, local visitor experience. The tourism sector attracts investment, which makes it more sensitive to the natural environment. Kerala is a global brand in the field of tourism. We have increased our market share inside and outside India. Cultural tourism is gradually gaining wide acceptance as a real tourist destination and becoming one of the most promising areas of economic development of our country. Cultural tourism products in Kerala are not marketed properly. Cultural tourism is gaining more and more tourists these days. It is a common fact that tourists may be more interested in the culture of the native place they visited than the hosts. Culture is associated with religions, beliefs, customs, traditions, languages, rituals, arts, and the way of life of people living in a particular geographical area. This study highlights the analysis of the growth rate of Kerala tourism and analyzes the cultural tourism potential of Kerala.
\end{abstract}

Keywords: Cultural tourism, Cultural tourism products

(C) 2021 Jaseela Thanikkad and Shanimon, S. This is an open access article under the CC BY license (https://creativecommons.org/licenses/by/4.0/), which permits unrestricted use, distribution, and reproduction in any medium, provided you give appropriate credit to the original author(s) and the source, provide a link to the Creative Commons license, and indicate if changes were made.

\section{Introduction}

Tourism is a global economic activity. It is a temporary movement of people from one place to another, mainly for pleasure. It is a fast-growing industry employs millions of people, creates foreign exchange, promotes balanced local development and revives art and culture. It is one of the largest industries in the world. Tourism is not a single industry but a group of industries that work together and complement each other. India is a country blessed with 5000 years old civilization, rich in natural resources, and coupled with geographical and cultural diversity. Visiting India is an exciting and timeless experience for all. It is a tourist paradise that showcases all the features of traditional hospitality and modernity. The rich cultural heritage of the country attracts the attention of thousands of tourists. Kerala is known as 'God's own country'. The state is rich in natural resources for tourism development such as beautiful hill stations, dense forests, lakes, waterfalls, backwaters, lakes, rivers and beaches. Climate, friendly, friendly and literate people, exotic wildlife, monuments, colorful fairs and festivals, hundreds of years of cultural heritage, exquisite art, handicrafts and architecture attract the attention of tourists.

\footnotetext{
* Corresponding author: Jaseela Thanikkad, A ssistant Professor N M SM Government College, U niversity of Kannur, Kalpetta, Kerala 673122, India. E-mail: jaazthanikkad@gmail.com
} 
Tourism in Kerala has been identified as an important industry and hence the government is promoting it with high interest rates due to its greater efficiency in job creation. Kerala tourism is growing faster than Indian tourism and world tourism. Cultural tourism is gaining more and more tourists these days. It is a usual practice that tourists may have shown more interest than the hosts in the culture of the native place they visited. Culture is associated with religions, beliefs, customs, traditions, languages, rituals, arts, and the way of life of people living in a particular geographical area. Therefore, cultural tourism is a subdivision of tourism that deals with products such as art forms, fairs, festivals, historical sites, monuments, museums, cultural centers, religious buildings, painting, music, literature, poetry, drama, sculptures and handicrafts. , Folklore, architecture, archeological sites, etc.

\subsection{Operational Definitions}

For the purpose of the study cultural tourism is defined as the subset of tourism concerned with the cultural tourism products of a geographical area such as art forms, fairs and festivals, historical sites, monuments, museums, cultural centers, pilgrim centers, paintings, music, literature, poetry, drama, sculptures, handicrafts, folklore, architecture, archeological sites, etc.

\subsection{Statement of the Problem}

The Indian travel and tourism sector contributed nearly $\$ 194$ bn, around 6.8\% of GDP and nearly 13\% of the total employment of the country during calendar year 2019. According to the ranking of states and Union Territories (UTs) done on the basis of Domestic Tourist Visits (DTVs) and Foreign Tourist Visits (FTVs) in the country based on all India growth rate, Kerala ranks only 16 on the domestic front and $7^{\text {th }}$ in the foreign segment. So it is clear that we need more intensive researches to promote our tourism potential. When we consider the case of other prominent tourism destinations states of India like, Maharashtra, Andhra Pradesh, Rajasthan, Delhi, Uttar Pradesh, Tamil Nadu, etc., we can see that they are moving steps towards the promotion of "Cultural tourism to enhance their competitiveness and attractiveness. Therefore a study on "The Role of Cultural Tourism in the Tourism Development of Kerala" is highly required for tapping the neglected and hidden potential of our Cultural Tourism Products in order to improve the efficiency of the tourism of the state".

\section{Objectives of the Study}

In order to put the investigation in its proper perspective, the following objectives are formulated.

1. To analyze the growth of Kerala tourism.

2. To identify the major Cultural Tourism products of Kerala

\section{Methodology}

This study is descriptive and analytical in nature and is based on secondary data only. Secondary data is collected from the published records of Ministry of Tourism, Government of India; publications of Department of Tourism, Government of Kerala; publications of World Tourism Organization and other published records related to tourism for the period from 2010 to 2019.

\section{Growth of Kerala Tourism}

Kerala is one of the most popular tourist destinations in India. Elevated as "God's Own Country", the state has various tourism assets such as beaches, hill stations, lakes, national parks and wildlife sanctuaries. However, the key to the success of tourism is its consistent marketing efforts and the creation of new tourism products. As a result, Kerala has become a model for planned tourism development to other Indian states. For example, National Geographic Traveler selected Kerala as one of the top 50 destinations. The success of tourism marketing in Kerala is due to a combination of factors: The clear identification and positioning of the tourism product and differentiating from other Indian states developing a basket of tourism activities. Close coordination between the state agencies and private sector for tourism marketing aggressive promotion and brand building to the target audience development of best practices and models for tourism development Introducing regulation and quality certification for tourism products.

Kerala's principal tourism products fall into six categories: (1) heritage/ cultural/religious sites \& events, (2) backwaters, (3) beaches, (4) hill stations, (5) wild life sanctuaries and (6) ayurveda, and the general environment. They combine to form a green symphony. In 2019, Kerala attracted 18,384,233 domestic tourists and 1,189,771 foreign tourists. The growth rate in the inflow of domestic tourist was $17.81 \%$ while it was $8.52 \%$ for the foreign tourist arrivals. Kerala initiated tourism development programs by establishing an international beach resort at Kovalam in 1976 with the patronage of the central 
government. Realizing the economic potentials, Government of Kerala declared tourism as an industry in 1986. Within a short span of two and half decades, Kerala succeeded in establishing its tourism brand in the international market. The first tourism policy of the state was announced in 1995 underlining the importance of public-private partnership. Tourism has come a long way since then, capturing new markets with its innovative products and marketing strategies. From hardly 50,000 foreign tourist arrivals and 0.13 bn rupees as foreign exchange in 1986, it has reached a status of 0.6 million foreign tourist arrivals and 45.48 bn rupees as foreign exchange in 2019. Total employment generated from tourism is estimated as 1.2 million.

Kerala Tourism Development Program was started in 1976 by setting up an international beach resort at Kovalam under the patronage of the Central Government. Realizing the economic potential, the Government of Kerala declared tourism as an industry in 1986. Within two and a half decades, Kerala has succeeded in establishing a tourism brand in the international market. Underlining the importance of public-private partnership, the state announced its first tourism policy in 1995. Tourism has since moved on to capture new markets with innovative products and marketing strategies. Kerala has reached the status of 1,189,771 foreign tourist arrivals and 10,271.06 cr rupees as foreign exchange in 2019. Around $23.52 \%$ of the total employment of Kerala is created directly or indirectly by the tourism.

The growth of Kerala tourism is studied with the help of available quantitative data, i.e., tourist arrivals and total tourism revenue over a period of 11 years. Tourist arrivals foreign tourist arrivals and domestic tourist arrivals can be divided into two. Kerala initiated tourism development programs by establishing an international beach resort at Kovalam in 1976 with the patronage of the central government. Realizing the economic potentials, Government of Kerala declared tourism as an industry in 1986. Within a short span of two and half decades, Kerala succeeded in establishing its tourism brand in the international market. The first tourism policy of the state was announced in 1995 underlining the importance of Public-Private Partnership. Tourism has come a long way since then, capturing new markets with its innovative products and marketing strategies. From hardly 50,000 foreign tourist arrivals and 0.13 bn rupees as foreign exchange in

\begin{tabular}{|c|c|c|c|c|}
\hline Year & $\begin{array}{c}\text { ForEign Tourist } \\
\text { Arrivals to } \\
\text { Kerala }\end{array}$ & $\begin{array}{c}\text { Percentage Change } \\
\text { Over the Previous } \\
\text { Year }\end{array}$ & $\begin{array}{l}\text { Foreign Tourist } \\
\text { Arrivals in India } \\
\text { (in millions) }\end{array}$ & $\begin{array}{c}\text { Percentage Change } \\
\text { Over the Previous } \\
\text { Year }\end{array}$ \\
\hline 2009 & 557258 & - & 5.17 & - \\
\hline 2010 & 659265 & $18.31 \%$ & 5.78 & $11.8 \%$ \\
\hline 2011 & 732985 & $11.18 \%$ & 6.31 & $9.2 \%$ \\
\hline 2012 & 793696 & $8.28 \%$ & 6.58 & $4.3 \%$ \\
\hline 2013 & 858143 & $8.12 \%$ & 6.97 & $5.9 \%$ \\
\hline 2014 & 923366 & $7.6 \%$ & 7.68 & $10.2 \%$ \\
\hline 2015 & $9,77,479$ & $5.86 \%$ & 8.03 & $4.5 \%$ \\
\hline 2016 & $10,38,419$ & $6.23 \%$ & 8.80 & $9.7 \%$ \\
\hline 2017 & $10,91,870$ & $5.15 \%$ & 10.04 & $14.0 \%$ \\
\hline 2018 & $10,96,407$ & $0.42 \%$ & 10.56 & $5.2 \%$ \\
\hline \multirow[t]{2}{*}{2019} & $11,89,771$ & $8.52 \%$ & 10.93 & $3.5 \%$ \\
\hline & & $\begin{array}{l}\text { Average growth rate }= \\
7.97 \% \text { over the } 10 \text { year } \\
\text { period } 2010-2019\end{array}$ & & $\begin{array}{c}\text { Average growth rate }= \\
7.83 \% \text { over the } 10 \text { year } \\
\text { period } 2010-2019\end{array}$ \\
\hline $\begin{array}{l}\text { Source: } \\
\text { of Tour }\end{array}$ & archer fron & of Tourist sto & Ban & $\begin{array}{l}\text { 2000-2015 (ii) Ministry } \\
\text { ruvananthapuram }\end{array}$ \\
\hline
\end{tabular}


1986, it has reached a status of 1,189,771 foreign tourist arrivals and 45.01 bn rupees as foreign exchange in 2019. Total employment generated from tourism is estimated as 1.2 million.

The growth of Kerala Tourism is studied with the help of available quantitative data namely, tourist arrival and income from total tourism over a period of 10 years. The tourist arrival can be divided into two as foreign tourist arrivals and domestic tourist arrivals.

From the Table 1, we can identify that the foreign tourist arrivals to Kerala is being increased $80.46 \%$ in 2019 , compared to 2010. The average growth rate of foreign tourist arrivals in Kerala is 7.97\%over the 10 year period $2010-2019$. But the foreign tourist arrivals to India are increased by $89.10 \%$ in 2019 , compared to 2010 . The average growth rate of foreign tourist arrivals in Kerala is $7.83 \%$ over the 10 year period 2010-2019. From this data we can conclude that the foreign tourist arrival to Kerala is increasing at a higher rate than the foreign tourist arrival to India.

From the Table 2, we can analyze that the domestic tourist arrivals to Kerala is being increased $113.89 \%$ in 2019 , compared to 2010. The average growth rate of domestic tourist arrivals in Kerala is $8.84 \%$ over the 10 -year period 20102019. But the domestic tourist arrivals to India are increased by $247.18 \%$ in 2019 , compared to 2010 . The average growth rate of domestic tourist arrivals in Kerala is $6.69 \%$ and the domestic tourist arrivals to India is $13.4 \%$ over the 10 years period 2010-2019. From this data we can conclude that the domestic tourist arrival to India is increasing at a higher rate than the domestic tourist arrival to Kerala.

Table 2: Domestic Tourist Arrivals to Kerala and India from 2015 to 2019

\begin{tabular}{|c|c|c|c|c|}
\hline Year & $\begin{array}{c}\text { Number of Domestic } \\
\text { Tourist Arrivals } \\
\text { to Kerala }\end{array}$ & $\begin{array}{c}\text { Percentage Change } \\
\text { Over the Previous Year }\end{array}$ & $\begin{array}{c}\text { Number of Domestic } \\
\text { Tourist Arrivals In India } \\
\text { (in mn) To All States/UTs }\end{array}$ & $\begin{array}{c}\text { Percentage Change } \\
\text { Over the Previous } \\
\text { Year }\end{array}$ \\
\hline 2009 & 7913537 & - & 668.80 & - \\
\hline 2010 & 8595075 & $8.61 \%$ & 747.70 & $11.8 \%$ \\
\hline 2011 & 9381455 & $9.15 \%$ & 864.53 & $15.6 \%$ \\
\hline 2012 & 10076854 & $7.41 \%$ & 1045.05 & $20.9 \%$ \\
\hline 2013 & 10857811 & $7.75 \%$ & 1042.53 & $9.3 \%$ \\
\hline 2014 & 11695411 & $7.71 \%$ & 1282.80 & $12.3 \%$ \\
\hline 2015 & 12465571 & $6.59 \%$ & 1431.97 & $11.6 \%$ \\
\hline 2016 & 13172535 & $5.67 \%$ & 1615.39 & $12.8 \%$ \\
\hline 2017 & 14673520 & $11.39 \%$ & 1657.55 & $2.6 \%$ \\
\hline 2018 & 15604661 & $6.35 \%$ & 1853.79 & $11.8 \%$ \\
\hline \multirow[t]{2}{*}{2019} & 18384233 & $17.81 \%$ & 2321.98 & $25.3 \%$ \\
\hline & & $\begin{array}{l}\text { Average growth rate }= \\
8.84 \% \text { over the } 10 \text {-year } \\
\text { period } 2010-2019\end{array}$ & & $\begin{array}{c}\text { CAGR }=13.4 \% \\
\text { over the } 10 \text {-year period } \\
2010-2019\end{array}$ \\
\hline
\end{tabular}

Source: Compiled by the researcher from various issues of Tourist statistics, (i) Reserve Bank of India, for $2000-2015$ (ii) Ministry of Tourism, Govt. of India, for 2016-2019, and (iii) Department of Tourism, Government of Kerala, Thiruvananthapuram

From the Table 3, in the year 2010, the foreign exchange earnings of Kerala was 3797.37 crores, but in 2019 it is increased to 10,271.06 crores. Which means that over a period of 10 years, foreign exchange earnings of Kerala has been increased by $170.49 \%$. Whereas, the total earnings from the tourism are increased by $159.45 \%$, during this period. The average growth rate of foreign exchange earnings is 13.93 and the total earnings is $14.8 \%$ over the 10 -year period. 
Table 3: Showing Foreign Exchange Earnings and Total Earnings to Kerala Out of Tourism (Rs. in cr)

\begin{tabular}{|c|c|c|c|c|}
\hline Year & $\begin{array}{c}\text { Foreign Exchange } \\
\text { Earnings in Tourism } \\
\text { of Kerala }\end{array}$ & $\begin{array}{c}\text { Percentage Change } \\
\text { Over The Previous } \\
\text { Year }\end{array}$ & $\begin{array}{c}\text { Total Revenue Generated } \\
\text { From Tourism(Direct and } \\
\text { Indirect) }\end{array}$ & $\begin{array}{c}\text { Percentage Change } \\
\text { Over The Previous Year }\end{array}$ \\
\hline 2009 & 2853.16 & - & 13231.00 & $31.12 \%$ \\
\hline 2010 & 3797.37 & $33.09 \%$ & 17348.00 & $9.74 \%$ \\
\hline 2011 & 4221.99 & $11.18 \%$ & 20430.00 & $7.32 \%$ \\
\hline 2012 & 4571.69 & $8.28 \%$ & 22926.55 & $12.22 \%$ \\
\hline 2013 & 5560.77 & $21.63 \%$ & 24885.44 & $12.11 \%$ \\
\hline 2014 & 6398.93 & $15.07 \%$ & 26689.63 & $7.25 \%$ \\
\hline 2015 & 6949.88 & $8.61 \%$ & 29658.56 & $11.12 \%$ \\
\hline 2016 & 7749.51 & $11.51 \%$ & 33383.68 & $12.56 \%$ \\
\hline 2017 & 8392.11 & $8.29 \%$ & 36258.01 & $8.61 \%$ \\
\hline 2018 & 8764.46 & $4.44 \%$ & 45010.69 & $24.14 \%$ \\
\hline 2019 & 10271.06 & $17.19 \%$ & & Average growth rate $=$ \\
\hline & & Average growth rate & & $2010-2019$ \\
\hline
\end{tabular}

Source: Compiled by the researcher from various issues of Tourist statistics, (i) Reserve Bank of India, for 2000-2015, (ii) Ministry of Tourism, Govt. of India, for 2016-2019, and (iii) Department of Tourism, Government of Kerala, Thiruvananthapuram

\section{Cultural Tourism Prospects of Kerala}

Cultural Tourism products of Kerala are gaining more acceptance among people around the world and cultural factors are attracting many tourists to their destinations. Cultural tourism products significantly affect the growth of our tourism industry. The cultural heritage of Kerala shows a broad spectrum of many unique factors. The rich culture and heritage of the state enhances the quality of the tourist experience. In Kerala, tourists can experience the diversity of the culture of the state. Art, artifacts, handicrafts folklore, architecture, historical sites, monuments, archaeological sites, paintings, music, literature, poetry, drama, sculptures, museums, cultural sites, religious site such as temples, mosques, and churches, festivals like Onam, Vishu, Trissur Pooram, boat races, etc. reflect the cultural heritage of the state, which attracts thousands of tourists. Tourism is becoming a vibrant and important contribution to the sustainable development of Kerala. The state offers a world-class but local visitor experience. The tourism sector in Kerala attracts investment, which is sensitive to the natural environment. Communities benefit from tourism and appreciate its contribution. Kerala is positions as a global brand in tourism. We have increased our market share inside and outside India. Kerala is becoming a provider of quality human resources in tourism for the state and the nation.

Kerala's Tourism Assets - Categorization: The various tourist attractions in Kerala can be classified broadly as cultural attractions and natural attractions.

\begin{tabular}{|l|l|}
\hline Cultural Attractions & Natural Attractions \\
\hline 1. History, architecture, archeology & 1. Beach, 2. Backwater 3. Picnic spot, \\
2. Culture, heritage, arts and crafts & 4. Hill station, hill, mountain, peak, \\
3. Museum, palace & 5. Wildlife/bird sanctuary, forest. \\
4. Fort & 6. Waterfalls, 7. Lake \\
5. Religious place, pilgrimage centre, places of worship & \\
\hline
\end{tabular}


Pilgrimage centers / places of worship are significantly represented in the list. While many of them do not have a broad ecumenical appeal, they do attract a large number of devotees and pilgrims from far and near. A major portion of our tourism products is cultural tourism products.

\subsection{Most Popular Cultural Tourism Products of Kerala}

\subsubsection{Fairs and Festivals}

Fairs and festivals are unique in Kerala. Onam is the main festival of Kerala. There are many religious festivals in Kerala. Thrissur Pooram and Chettikulangara Bharani are the major temple festivals in Kerala. Thrissur Pooram is held at the Vadakummanathan Temple in Thrissur. Chettikulangara Bharani is another major attraction. The fair is held at the Chettikulankara temple near Mavelikkara. Shivratri is also an important festival in Kerala. The festival is celebrated mainly at the Aluva Temple and the Patanilam Parabrahma Temple. Padanailam Temple is located in the Alappuzha district of Kerala, at a distance of $16 \mathrm{~km}$ (9.9 miles) from the town of Mavelikkara. Parumala Perunal and Manarkat Perunal are the major Christian festivals. Muslims also have many important festivals. Tourists from all over the world come to enjoy the fairs and festivals of Kerala during the festival season.

\subsubsection{Pilgrim Centers}

Pilgrimage centers are another major cultural and tourist attraction in Kerala. The pilgrimage centers in the state are world famous. Lakhs of tourists from Kerala and outside Kerala visit the pilgrimage centers in the state. Sabarimala, Guruvayur Sri Krishna Temple, Sri Padmanabha Swamy Temple, Potta Division Retreat Center, Malayattoor Church, Parasurama Temple, Parasinikkadavu Muthappa Temple and the Jewish Synagogue in Mattancherry are some of the famous pilgrimage centers in Kerala.

\subsubsection{Arts}

The culture of Kerala is mainly of Dravidian origin, originating from a greater Tamil heritage known as Tamilkam, which later explained the culture of Kerala through centuries of contact with overseas cultures. Native performing arts include Koodiyattam Kathakali - Kathai ("Story") from Kali ("Play") - its off-shoot Kerala Natanam, Koothu (similar to stand-up comedy), Mohiniyattam ("Dance of the Magician"), Thullal, Padayani and Theyyam. Other arts are more religious and tribal-themed. These include Chavittu Natakam, Opana (originally from Malabar), dance, rhythmic applause and Ishaal sounds. However, many of these works of art are mainly played by tourists or at youth festivals, and are not popular among most ordinary Keralites. These people are looking at more and more contemporary art and performance styles that use imitation and parody. Many ancient ritual arts are of Kerala origin; These include kalaripayattu (kalari means "place", "threshing floor" or "battlefield"), and payattu ("exercise" or "training"). Among the oldest martial arts in the world, oral tradition attributes kalaripayattu's emergence to Parasurama. Other ritual arts include Theyyam, Poorakali and Kuthiyottam.

Kuthiyottam is a ritualistic symbolic representation of human bali (homicide). The folk art form is considered by folk artisans to be one of the rare Adi Dravida folklore traditions still preserved and practiced in Central Kerala in keeping with the original tradition and environment. Similar to the Adi Dravidian folk dances and songs, the movements and forms of the dancers who danced in the kuthiyottam (clad in white thorthu and banyan) are quick and at a certain point the peaks end abruptly. Traditional songs also start at a stylish slow pace, then gain speed and end quickly. Kuthiyottam Kalaris, conducted by Kuthiyottha Ashans (teachers or leaders), trains the group to perform dances and songs. Training usually starts one or two months before the season. Boys between the ages of 8 and 14 are taught ritual dance at home during a large community gathering in front of a portrait of the diety. In the early morning Bharani, after the feast and other ceremonies, the corpses are wrapped in silver wire, one end of which is tied around the neck, and an anklet is taken, which is fastened to the tip of a knife held high above the head are taken in procession to the temple with drums, music, decorative umbrellas, other classical folk art forms, and abundant capricorn elephants. Along the way to the temple, young coconut water was constantly poured on his body. After the circumambulation, the boys stands at a position facing the Sreekovil and begins to dance. This ceremony ends with dragging the coil pierced to the skin whereby a few drops of blood comes out.

\subsubsection{Culinary tourism}

Kerala is rich in spices, fruits, vegetables, coconut and seafood. Different types of vegetarian and non-vegetarian dishes attract tourists. Kerala has a unique cuisine like its cultural life, influenced by its long coastline and all the wide range of coconuts and delicacies, it is rich in exotic fruits, vegetables and seafood, and is complemented by the aroma of spices. 


\subsubsection{Shopping}

The Government of Kerala launched the Grand Kerala Shopping Festival in 2007 to further promote tourism in Kerala. Since then it has become an annual shopping event held between December and January. Stores and shops registered under GKSF during this period offer numerous discounts and VAT refunds. In addition to the guaranteed shopping experience, shoppers are offered gift coupons for a fixed value purchase to access weekly and mega lucky draws. Compared to the shopping festivals held in other countries, this festival makes Kerala a huge shopping mall, attracting not only big players but also small and medium enterprises. Through this shopping festival, the Government of Kerala intends to make the state a hub for international shopping experiences and to launch "shopping tourism" there.

\subsubsection{Events}

Kerala is famous for many events organized by the Ministry of Tourism for tourist destinations. Kochi, Muzir's Biennale, India's first Biennale was held in Kochi from December 12, 2012 to March 13, 2013. The government contributed 12-150 million to the event. An International Coir Fest is organized every year with the objective of developing the coir industry and tourism in Kerala.

\subsection{Palaces, Museums, Monuments, Architecture, History and Cultural Centers}

The State Tourism Department highlights our historic, archeological and artistic palaces and sites as a strong tourism product, and attracts a large number of tourists. Most important cultural centers are museums, palaces, monuments, historic centers, other cultural institutions and tourist attractions.

\subsubsection{Palakkad Fort}

It was built by Hyder Ali of Mysore who conquered the northern part of Kerala in the $18^{\text {th }}$ century. This fort is also known as the fort of Tipu Sultan. It is named after the son of Hyder Ali. It was later conquered by the British after the fall of Tipu Sultan. Pallakkad Fort is located in the heart of the Palghat region.

\subsubsection{Napier Museum}

Without this unique museum of historical artifacts, no discussion of the most famous heritage sites in Kerala can begin. The Napier Museum was built in the $19^{\text {th }}$ century and is a beautiful example of a natural air conditioning system. The history of Kerala is enlivened by the handicrafts preserved for all to see-bronze idols, chariots, exquisitely carved antique ornaments and ivory carvings make this place an unforgettable visit. Visitors to Kerala should always try to visit this place.

\subsubsection{Koyikkal Palace}

The palace is located at a distance of $18 \mathrm{~km}$ from Thiruvananthapuram near the Ponmudi Hill Station. Built in the $15^{\text {th }}$ century, this magnificent building is a perfect example of royal splendor. Tourists visiting Kuttalam water Falls should stop here to experience the prosperity that was inherent in Kerala in the past.

\subsubsection{Koder House}

Kerala is one of the other lineages of traditions and heritage. There is also a large Jewish lineage. Koder House is one of the most famous heritage sites in Kerala that bears witness to this rich heritage. It was built in 1808 by the Jewish patriarch Samuel Koder. Koder is associated with the famous Kochi Electric Factory. It is an excellent example of IndoEuropean style, which was a model of Cochin architecture. The modernity of the Jewish way of life is reflected in the furniture and decorations of the house.

\subsubsection{Jewish Synagogue}

Built in 1568 by the Jewish settlers from Mattancherry, it is a magnificent, attractive and artistic structure. They were expelled from Rahabi. The tiles were brought in by specialized Chinese designers depicting hand-painted willow patterns. The clock tower is a reminder of Jewish architecture.

\subsubsection{Krishna Menon Museum}

Named after the world famous intellectual, this museum is located at a distance of $5 \mathrm{~km}$ from East Hill in Kozhikode. This is a place that is considered a treasure trove of knowledge. Many rare books can be seen in this museum. The heritage of the sub-continent, especially the history of Kerala is well represented and preserved in the ideas reflected in this museum. 


\subsubsection{Kirtad Museum}

If we are to be drawn into the depths of Kerala's history through its historical artefacts, sculptures and architectural heritage, then the adivasis and locals of the state and their livelihoods dating back thousands of years need to find a special place in our consideration. The museum is one of the most important heritage sites in Kerala and is an important witness to the local traditions and art. And an abbreviation of the Kerala Institute of Research. The development of Scheduled Tribes and Scheduled Tribes is dedicated to the natives of the State. Adivasi culture has its roots in the pre - Aryan background which has flourished since prehistoric times and still has its flag bearers in the form of thriving tribes in the state .This Ethnological Museum in Kerala reflects the history of the adivasi people. In these museums, the physical and spiritual heritage of the indigenous people is well documented. One finds bows and arrows of various sizes, tribal ornaments, pottery, utensils, handicrafts and the artistic aspirations of the tribal people. Indigenous handicrafts never fail to entice someone who is a little curious about this other lifestyle.

\subsubsection{St Angelo Fort}

This huge fort is also known as the Kunnar Fort. The gigantic triangular latitudinal structure is the view that appears in the background of the clear infinite sky. Many lakes and bastions adorn the building, a manifestation of the power of the rulers.

\subsubsection{Pazhassiraja Museum}

In the middle of Kozhikode, this museum has a rich collection of handicrafts. Mural paintings are a must see. The coins found here date back to the early Christian era. Miniatures are an excellent example of craftsmanship.

\subsubsection{Thallassery Fort}

The fort is located at a distance of $20 \mathrm{~km}$ from Kannur. It was a stronghold of the British people, a decent-sized military base built in 1708. Each stone of the fort symbolizes the power of the old rulers and observes British architecture and design.

\subsubsection{Ambalavayal Museum}

Evidence of the developed civilization that developed in Kerala in the $2^{\text {nd }}$ century AD is well documented in this museum. It is a heritage museum that reflects the origins of the complex cultural structure of Kerala. Preserved handicrafts are one of the largest collections in the state. It is amazing to observe the richness of the history of this region. It is located in Wayanad and is easily accessible by road.

\subsubsection{Archaeological Museum}

This building is often considered an archeological pleasure; The architecture is unique. It was built relatively recently and is housed in the Thrissur Town Hall. The archaeological museum, which is richly decorated and represents the history of this state, has a collection of admirable objects.

\subsubsection{Bastion Bungalow}

It was built in $1667 \mathrm{AD}$ by Dutch architects in a hybrid Indo-European style. The place is rich in Dutch items and handicrafts - Dutch culture has left its mark on history. It was an old Dutch fort and anyone interested in Dutch culture how it influenced the synthesis that made this assimilation possible. It gets its name from Stromberg Boston.

\subsubsection{Bekal Fort}

The fort and the adjoining beach are a major tourist. It is also the largest fort under the protection of the Archaeological Survey. It was turned into a tourist complex. While enjoying all the modern conveniences of the modern era, one encounters the new and the old that can revive the beautiful views of history.

\subsubsection{Bulgotty Palace}

Among the many historical heritage sites of various Western or European traditions, Kerala can boast of a rich Dutch heritage dating back to the days of the spice trade, and this beautiful palace is a testament to that history, and one of the most unique and popular heritage sites in Kerala. It is a remnant of Dutch heritage and was built in 1744 on an island in Cochin on the Arabian Sea. You can reach this place via Ernakulam. The palace was inhabited by the governors of the Dutch East India Company, which was later taken over by the English. Dutch and English handicrafts are well preserved in this palace. Those interested in making a European contribution to the culture of the country should visit this place. 


\subsubsection{Bishop's House}

The Bishop's House is the home of the oldest Catholic dioceses in India. Situated close to the Parade Ground, Fort Kochi is one of the most visited and popular heritage sites in Kerala. It was built by the Portuguese in 1506. The Portuguese history of Kerala is well documented in this place.

\subsubsection{Anchunthengu Fort}

Located near the capital city of Thiruvananthapuram, it is a remnant of British architecture. This form is the oldest and most important trading center of the British on the Malabar coast. The nearby cemetery is reminiscent of the glory and emptiness of death. The fort is strongly built.

\subsubsection{Bay Island Driftwood Museum}

A museum that showcases a unique collection of high quality driftwood articles of very high artistic value, created through a unique and innovative modern art form. A visitor can see a large collection of root sculptures of various shapes and designs here.

\subsubsection{Tea Museum}

Tea lovers from all over the world flock to this museum for its tea-making heritage and the wonderful aroma of its diverse leaves. Built by Tata Tea at the Nallathani Tea Garden in Munnar, this heritage site showcases the history of tea cultivation and the technologies of the tea industry that have evolved over time. There are displays of rare photographs and samples of machinery used at different times. Everything from rollers used in the past to fully automated tea processing machines are on display in museums. Tea lovers and curious visitors alike will enjoy the look and intricacies of caring for this world-winning leaf before serving it to us in cups. Anyone visiting Munnar should visit this museum to enjoy this experience and sight.

\subsubsection{Thakur House}

The former Kunal House or Hill Bungalow, Thakur House, is a vibration of the atmosphere of the last colonial period. The heavy furniture, large and airtight rooms and the natural breeze from the sea make it a cool place to relax your nerves and you can thank this place for a great vacation. It faces the sea and seven bastions built by the Dutch. The sand and the sea and the memories of the centuries left give one nostalgia for the romanticism of the British period.

\subsubsection{Shree Chirta Art Gallery}

Located inside the Napier Museum, the Sree Chitra Art Gallery boasts a fine collection of paintings by Raja Ravi Varma, one of the finest painters in Kerala. He was a painter with a realistic style, portraying members of the royal family, and prominent figures of the time. One enters into the past by looking at paintings. There are paintings of notable painters include Svetlova and Riorich. The traditional art schools of North and South India, the Rajasthan Art School, the Tanjore Art School and the Bengali school of the early $20^{\text {th }}$ century are all on display in this museum.

\subsubsection{Vasco House}

It is believed to be the first European settlement to set foot in Kerala and is one of the oldest surviving models of Portuguese architecture. The house may have been built by Vasco da Gama himself, and a visit to the site gives one an idea of the lifestyle of the first European settlers. It may have been built in the $16^{\text {th }}$ century and near the Kochi Fort.

\subsubsection{Maritime Museum}

The navy of the rulers of Kerala has always been strong as the long coastline has posed a serious challenge to the security of the old nations. The history of this evolution of the Navy from the Marakers to the present day is well preserved in this museum. Located in Kochi, the Maritime Museum offers a glimpse into the naval power of the country at the moment. It is located at INS Dronacharya in Kochi; The Maritime Museum is a must visit for everyone.

\subsubsection{Mannadi}

Located at a distance of $13 \mathrm{~km}$ from Adoor, this place is reminiscent of the great Veluthampi Dalawa, a Diwan of Travancore who once lived in his last days and faced his grief at this house. He led a small uprising against the British and claimed to have committed suicide instead of surrendering to his opponents. A monument has been erected in his memory as this old freedom fighter is highly revered by the locals. 
Krishnapuram Palace: It is one of the most famous heritage sites in Kerala with a rich artistic heritage. It was built by Muthanda Varma in the $18^{\text {th }}$ century; The palace is a repository of Kerala's architectural details and unique designs. It is located at a distance of $50 \mathrm{~km}$ from Alappuzha. Visitors often visit Kollam. Surrounded by a beautiful garden, the palace was recently adorned with a Buddhist mandapam. The main attraction of this place is the rare sculptures, exclusive paintings and antique bronze collections. Architectural method.

\section{Findings of the study}

- In 2019, Kerala attracted 18,384,233 domestic tourists and 1,189,771 foreign tourists. The growth rate in the inflow of domestic tourist was $17.81 \%$ while it was $8.52 \%$ for the foreign tourist arrivals.

- The total revenue, both direct and indirect, from the tourism sector touched Rs.45,010 cr in 2019 , compared to Rs. 17,348 cr in 2010.

. Forex earnings received by the tourism industry in the State went up from Rs. $2,853.00 \mathrm{cr}$ in 2010 to Rs. $10,271 \mathrm{cr}$ in 2019 .

- Statistics compiled by Kerala Tourism show that the State achieved an $8.58 \%$ variation in foreign tourist arrivals and $17.81 \%$ in the case of domestic tourist arrivals during 2019.

- Kerala tourism industry is very much affected by the cultural tourism products of Kerala.

- Foreign tourist arrival to Kerala is increasing at a higher rate than the foreign tourist arrival to India

\section{Conclusion}

It is only recently that the true tourism potential of this culture has begun to be appreciated and recognized. We have cultural tourism products such as art forms, fairs, festivals, handicrafts, folklore, architecture, historical sites, monuments, archeological sites, paintings, music, literature, poetry, drama, sculptures, museums and pilgrimage centers. But the products still do not attract as many tourists as we expect. Heritage and cultural tourism is an important component of domestic and foreign countries tourists visiting the state. It is essential to identify and focus on the available assets that are sufficient to attract and satisfy the diverse interests. In addition to developing Kochi as a heritage center, it has the potential to promote a heritage circuit that includes Kochi, Tripunithura, Kodungallur and Chennamangalam. Important museums may be upgraded to international standards with up-to-date interpretation systems and interactive audiovisual facilities. Museum retailing is an element that needs renovation. Possible models for tourism development that draw strength from local culture, art and lifestyle include business tourism packages that include rural tourism, the development of a heritage village, cultural performances and local cuisine. Suitable components of these models can be incorporated into various projects, or through these projects specific projects can be considered in appropriate places in the state. Kerala has stricter entry restrictions and dress codes for Hindu temples than any other state in India. One issue that deserves the consideration of the temple authorities is that the restrictions are at least selective. Specific areas of major temples, such as exquisite sculptures, woodwork, murals, and temple museums, can sometimes be considered open to tourists, not compromising on basic decor with a relaxing dress code. Christianity and Islam came to Kerala long before they were introduced in other parts of India. Some churches associated with St. Thomas and adjacent heritage churches may be part of the travel circuits that attract tourists with special interests.

\section{References}

Bansal.S.P, Prashant Gautam Sonia., Sushama. and Chander, Mohan. (2007). (Eds.). Cutting Edge Research in Tourism New Directions, Abhishek Publications, Chandigarh.

Cleverdon, R. (1979), The Economic and Social Impact of Tourism Developing Countries, The Economic Intelligence Unit. EIU special report, No. 60. 129-134.

Singh (1986), Conserving India’s Natural Heritage, Nataraj Publishers, Dehradun.

www.keralatourism.org

Kerala Tourism Policy, Department of Tourism, Government of Kerala. available at http://www.keralatourism.org/ Kerala\%20Tourism\%20Policy\%202012.pdf

Cite this article as: Jaseela Thanikkad and Shanimon, S. (2021). Sectoral Development of Cultural Tourism Centers in Kerala - A Study Based on the Specialities of Cultural Tourism Products in God's Own Country. International Journal of Tourism and Hospitality. 1(4), 1-10. doi: 10.51483/IJTH.1.4.2021.1-10. 